\title{
انفعالات يهوه النفسية في سفر التكوين
}

م.د. مسين عامر حسين أمين

وزارة التربية ــ الرصافة الأولى على علمين

الملخص

لكل إنسان عوامل نفسية تؤثر عليه في حياته وتتملك نفسه وهي اضطرابات نفسية عدة يتعرض لها

ذلك الشخص طوال حياته وتؤثر على سلوك حياته في الدنيا ومنها انفعال الغضب، والحزن، والنسيان، وحاشا

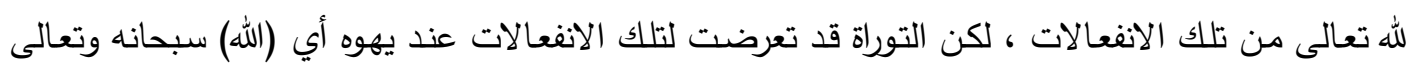
عن كل ذنب عظيم فقد صورته وهو في مشهد الغضب، والخوف، والحزن، والنسيان، لا بل يحتاج إلى من يذكره أيضاً في ذلك وفي البحث تفصيل لكل تلك الانفعالات. 
in Genesis The Psychological Emptions of Yahweh

Lect. Dr. Hussein Amer Hussein

\section{Abstract:}

Perhaps the psychological factors, and the accompanying and the psychological symptoms on man have a great effect on his life for the symptoms they leave on the behavior of individuals. But the thing is different when the mentions of Yahweh - means Almighty God- free He be mundane guilt. If we read the pages of the Torah we find that he passes through these emotions with all their negative and positive effects. That led us to stop at these mentions and starting under the title (The Psychological Emptions of Yahweh in Genesis). That title carries the word emotion in language and terminology, and also the definition of yahweh that was in the first inquiry. The second inquiry was about the emotion of fear in language and terminology, also we tackled the emtion of anger, forgetfulness in the last inquiry to reach up the conclusion which depicted Yahweh as a man that possesses these features as fear, sadness, regret and forgetfulness to insert the Torah in contradiction when we say that God goes through forgetfulness and needs someone to remind him. 
لعل العوامل النفسية، وما تصاحبها من أعراض نفسية فسيولوجية على الإنسان ذات تأثير عالٍ على حياته؛ لما تخلفه تلك الأعراض الناتجة عن انفعالات معينة على سلوك الفرد. لكن الأمر مختلف- أكيد عندما تكون تلك الانفعالات عند يهوه أي عند الله تعالى- حاشا لله عن

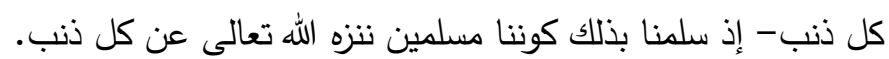

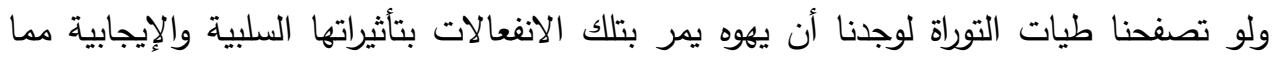

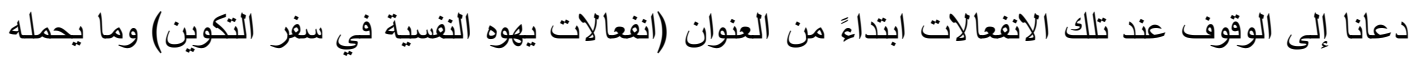

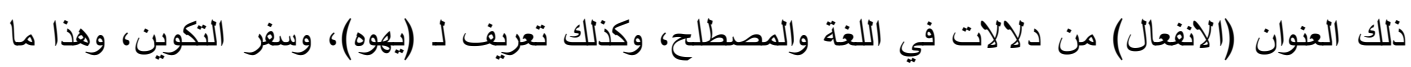

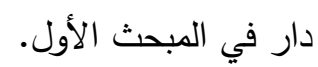

أما المبحث الثاني فتضمن الحديث عن (انفعال الخوف في اللغة والاصطلاح)ثم عرضنا لهشاهد

$$
\text { الخوف في التوراة. }
$$

وكان انفعال الغضب من الانفعالات التي شهدتها التوراة ليهوا أيضاً، لنصل إلى انفعال الندم الذي دي

يعقب الغضب أحياناً مصورين مشاهد الندم التي مر بها يهوه.

ولم تكتفِ التوراة بتلك الانفعالات، بل صورته أيضاً بمشاهد يتعرض بها للنسيان وهذا ما تحدثنا عنه في المبحث الأخير من بحثنا لنصل بعد ذلك لخاتمة البحث يليها قائمة المصادر والمراجع. 
المبحث الأول : التعريف بمصطحات العنوان :

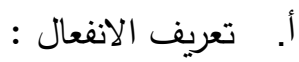

الانفعال لغة: وهو جمع انغعال، والانغعال من الفعل (انفعل) بمعنى تأثر ، وقد عرف (انفعل) بـ إتأثر به

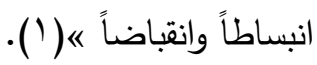

وقد عرف (المنعل) هو من اعتبر قبول الفعل في نفسه فهو أعم من المنفعل؛ لأن المنفعل يُقال لما

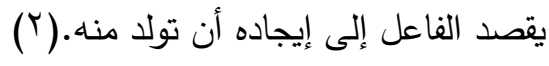
علماً أن هذا المصطلح لم يرد في توراة موسى، غير أن البحان البحث لم يلمس دلالاتها اللفظية، وإنما بقراءة عن معانيها اللغوية، وهذا نتيجة لما يظهر من مؤثرات عن تلك الثئ الثخصية - تعالى الله عنها - من خلال الآيات التي سندرسها.

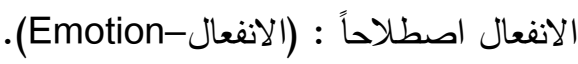
هو حالة وجدانية تتصف بجوانب معرفية خاصة واحساسات وردود أفعال فسيولوجية، وسلوك تعبيري

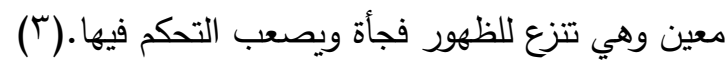

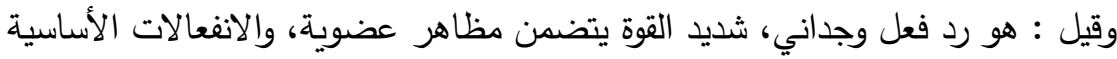

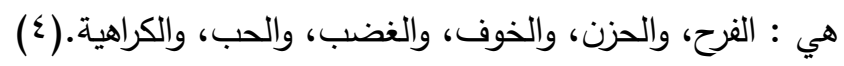

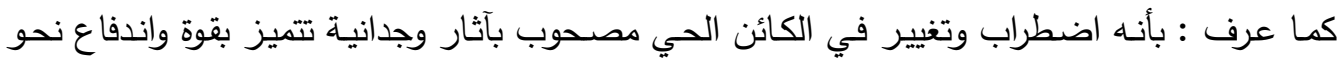

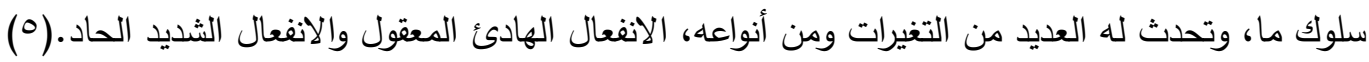

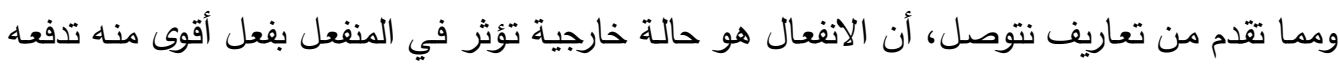

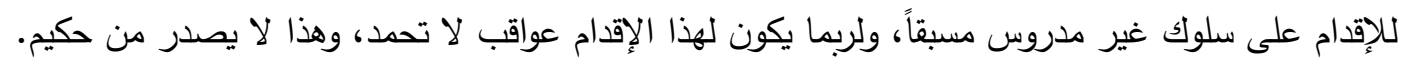

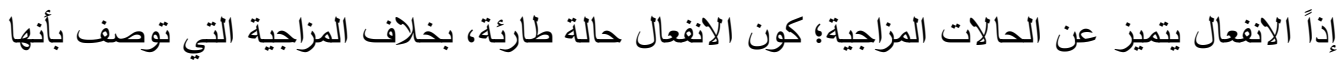

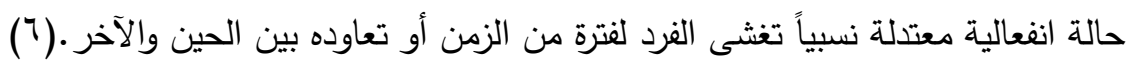

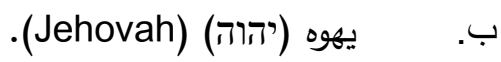

وهو أحد الأسماء الثمانية(V)، التي أطلقتها التوراة على (الله تعالى) وقد جاء هذا الاسم في التوراة لأول

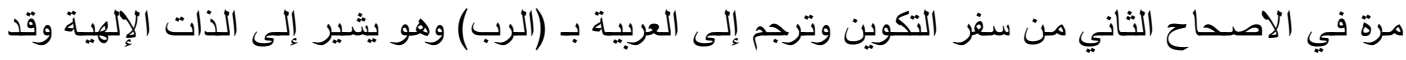

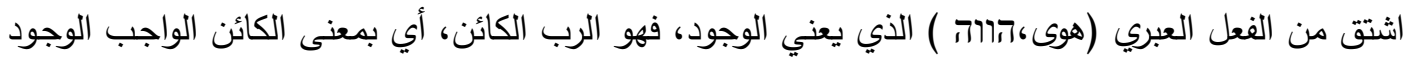

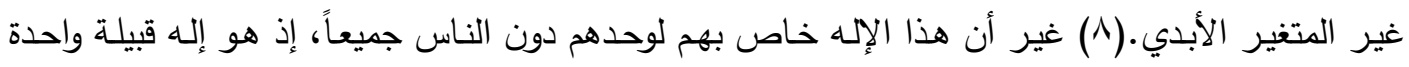

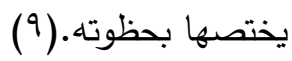


العـــــــد الثلاثون

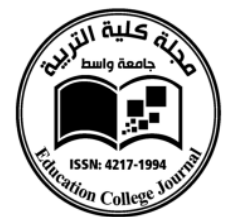

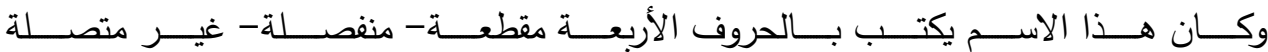

(י؛ ה ؛ן ؛ה)(ي، هـ، و، هـ) فكان رجال المقارى يتورعون عن النطق باسم الرب، إذ كان ذلك الاسم محرماً على اليهود، لذا استخدموا كلمة (الرب) عوضاً عنها ممتثلين لقول الرب: " لا تحلف باسم الرب إلهك باطلاً، لأن الرب لا ييرر من حلف باسمه باطلاً"( • () وكان لا ينطق بهذا الاسم إلا رئيس الكهنة. ج. سفر التكوين : (בראשית - Genesis)

ويسمى بالعبريـة (بريشت(1')،دראשית) أي (في البدء) لأنها أول كلمة وردت في السفر الأول من الاصحاح الأول في توراة موسى(Y ( ). بمعنى أنها أول كلمة في التوراة إذ جاء في الآية الأولى منه: وفي البـدء خلق الله السـماوات والأرض". سـفر التكـوين : 1 : 1 ؛ ويعتقـد أن هذا السـفر كتب بطريقتين الأولى بالنبوة (الروح القدس) الذي أوحى إلى موسى بكل الطرق الروحيةوالقصص المهمة المتعلقة

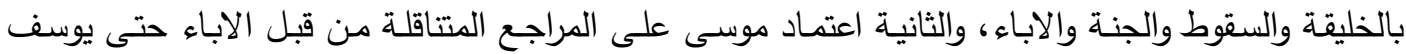

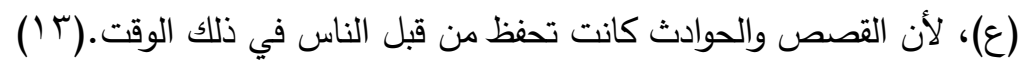
ويعتقد أن هذا السفر هو احد الأسفار الخمسة التي كتبها موسى (ع) بنفسه، ويتكون من (.0 خمسين) اصحاحاً(ع ())، وقد جاءت تلك الاصحاحات على قسمين: الأول، يبدأ من الاصحاح (1 (1 الى - (1) وهو

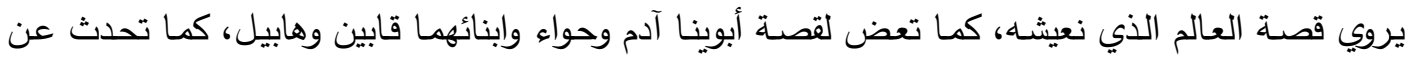
الطوفان، أما القسم الثاني فيبدأ من الاصحاح (Y إ- إلى -.0) وجاء في تلك الاصحاحات، كيف رتب الله الخلاص للبشرية، على يد الآباء الأولين، مبدئين بإبراهيم الذي عرف بإيمانه وطاعته الله.

(المبحث الثاني : انفعال الخوف(אימה)(Fright)

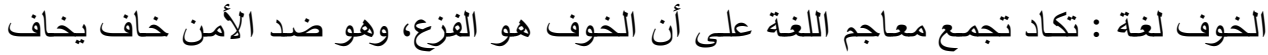

خوفاً (0 1)، وإنما صارت الواو ألفاً في يخاف لأنه على بناء (عمل - يعمل).(7 (1) اصطلاحاً: لقد عرف الخوف اصطلاحاً بتعاريف عدة فجاء فيه : أنه " توقع مكروه عن إمارة مظنونة أو معلومة، ويضاد الخوف، الأمن"(V)

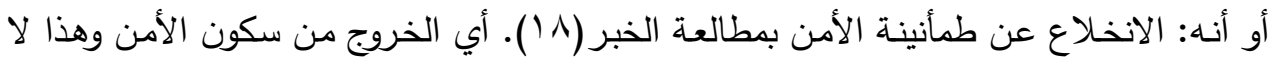
يكون إلا في المستقبل، ويعد هذا الانفعال من الانفعالات الهامة؛ لأنه يعين صاحبه على اتقاء الأخطار التي تهدده مما يساعد على الحياة والبقاء.(9 (19) وبهذا فإن المعنى الاصطلاحي لا يخرج عن المعنى اللغوي. ويذهب علماء النفس إلى جعل الخوف من حالات التوتر التي تصيب الفرد، ويقود الفرد الخائف إلى الهروب من الموقف الذي أدى إلى استثارة هذا الانفعال؛ لأن حالة الاضطراب الحاد التي تصاحبه تشمل 
العـــــــد الثلاثون

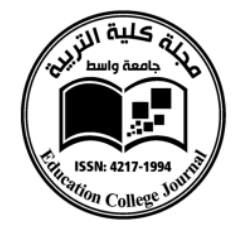

مجلـــة كليــة التربيــة

وتعم كل أجزاء الجسم؛ لذا عرف بأنه: شعور داخلي وانفعال يتعلمه الطفل نتيجة تعرضه لمؤثرات البيئة

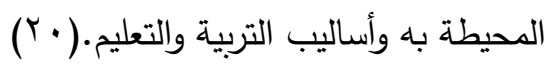

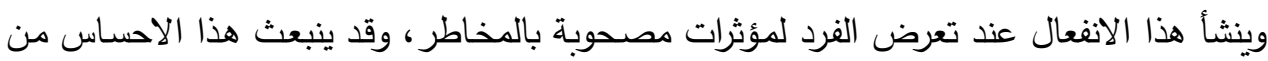

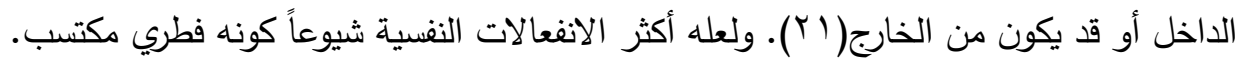
مشهد خوف يهوه في التوراة: (Scene fear of jehovah in the Bible)

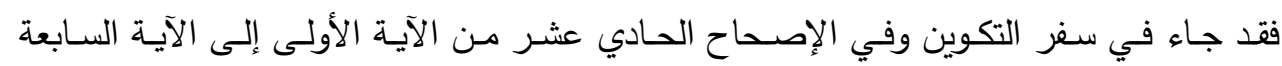

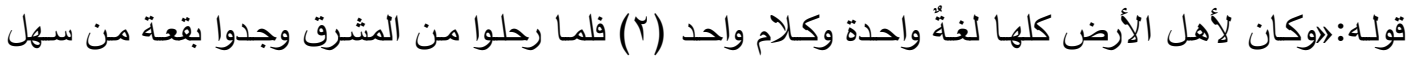

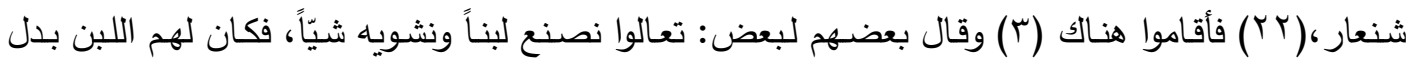

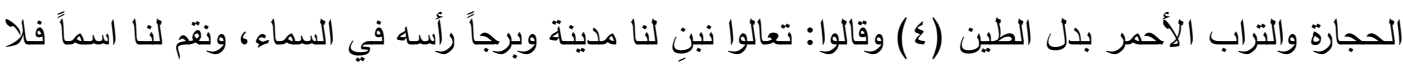

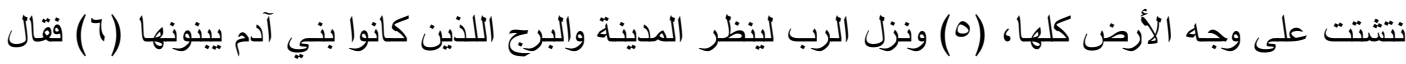

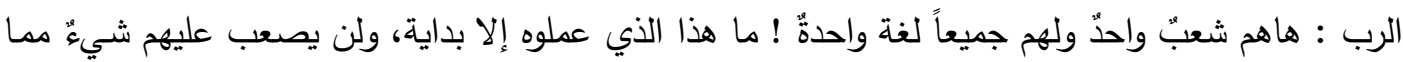

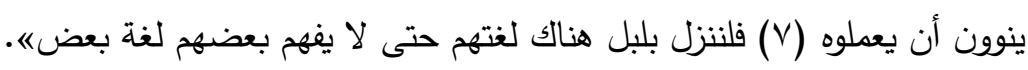

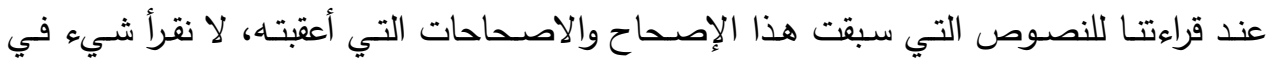
نصوص التوراة يكثف لنا عن الطريقة التي حصلوا بها عن القدرة على النطق والكلام التي ميزتهم عن سائر الترات

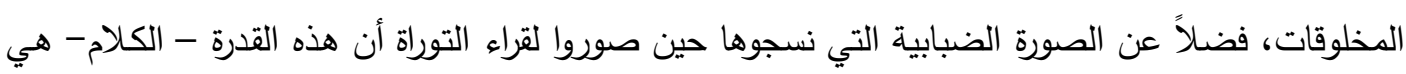

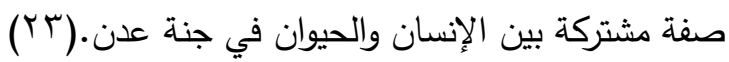

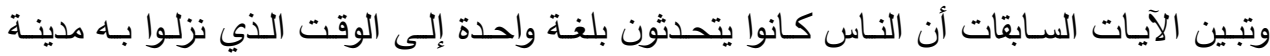

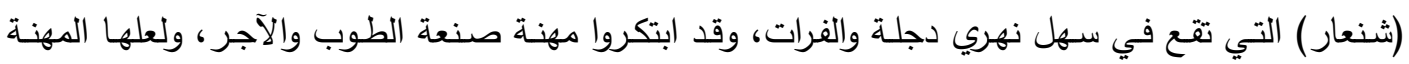

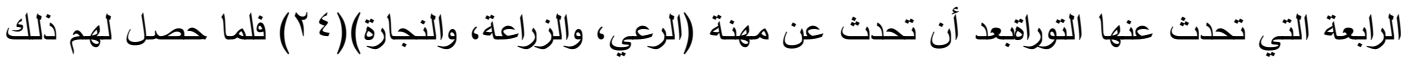

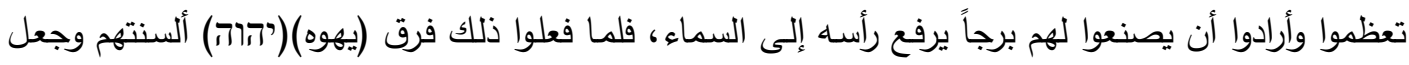

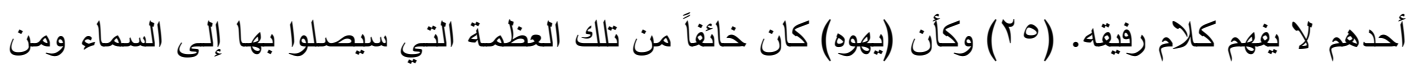
الاقتخار الذي سيفقده عبوديتهم له. ونحن نسأل هنا أي برج هذا يصل السماء حتى أن خالقها - حاشا لله- كان خائفاً من عظمة هذا

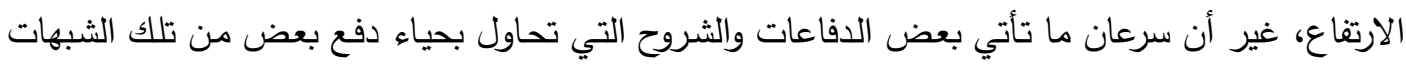

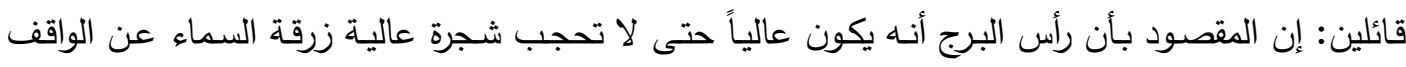

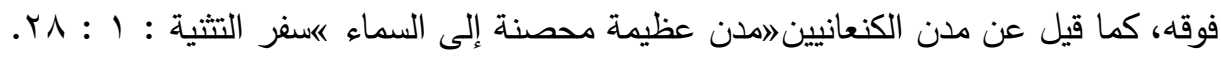


وليس المقصود أن البرج يرتغع حتى يصل إلى السماء إنما المقصود بما ينوون أن يعملوه هو الكبرياء

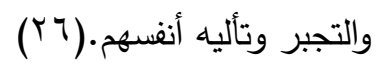

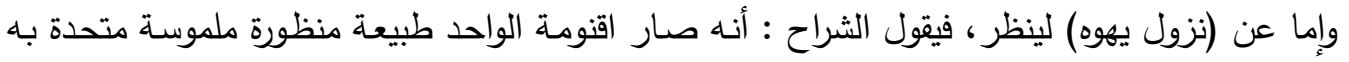

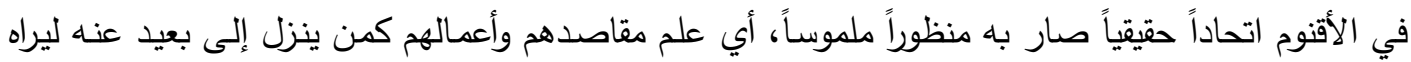

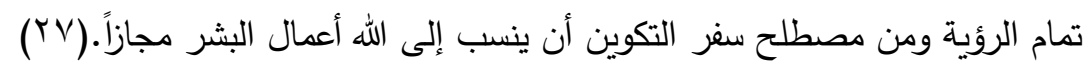

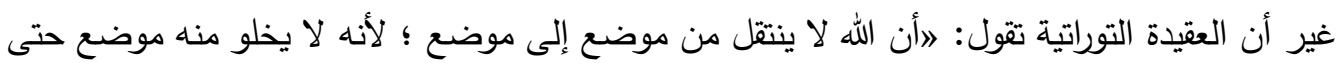

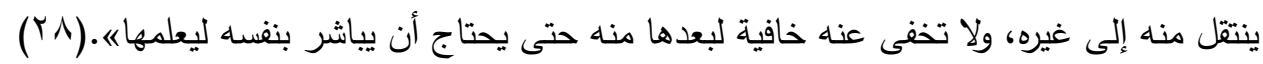

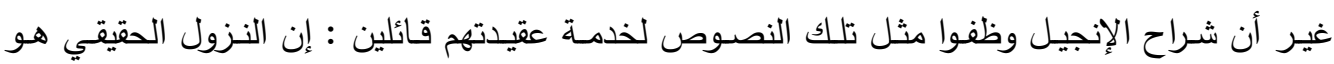
التجسيد ، وليس هذا النزول الذي يقصد منه الانتقال. وذكر هنا النزول لبني إسرائيل يروضهم بذلك التك ويدرجهم إليه حتى لا ينكروا النزول الحقيقي. وكأن قولهم هذا يصرح بأن بني إسرائيل كانوا لا يفهموا خفي نصوصهم.

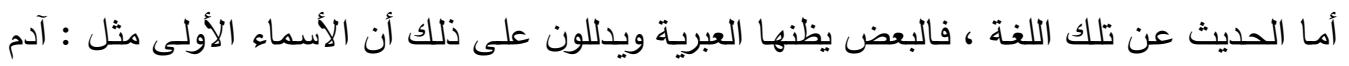

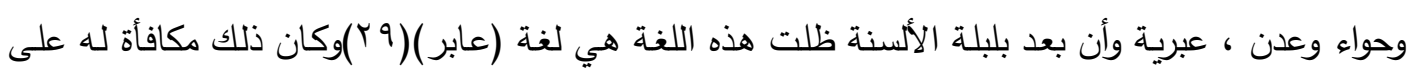

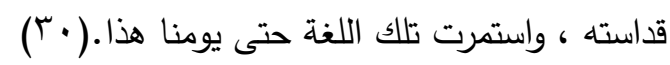

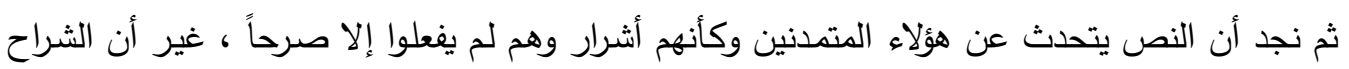

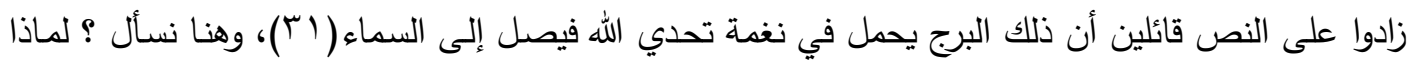

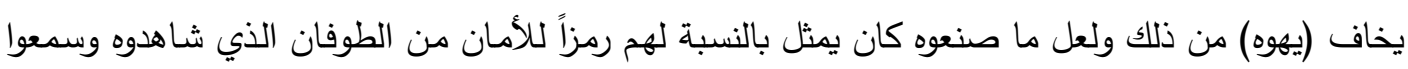
عنه.

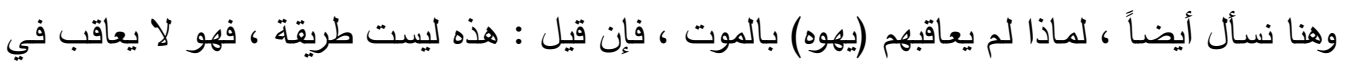

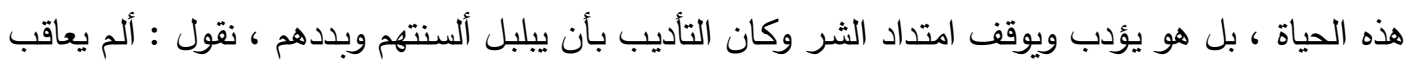

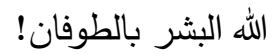

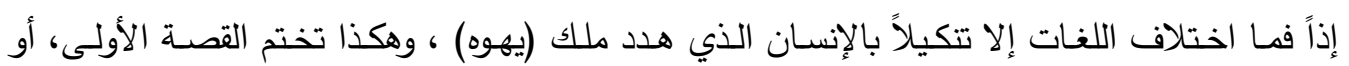

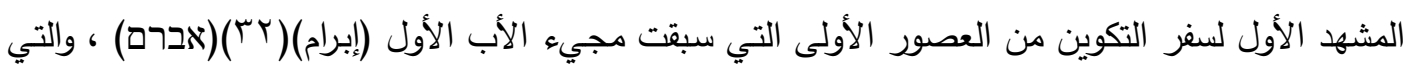
انتهت بتفريق الناس إلى بقاع العالم، وكان هذا المشهد ختم ليفتح مشهـ تاريخ بني إسرائيل. وكان تلك القصة كانت تهلف إلى إقناع القارئ بما يأتي: أ) إن اللغة الأم هي اللغة العبرية وقد تفرقت منها جميع لغات العالمات العالم.

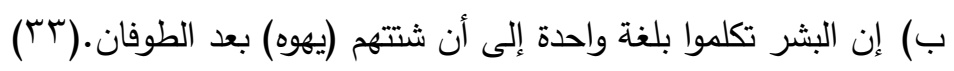


العـــــــد الثلاثون

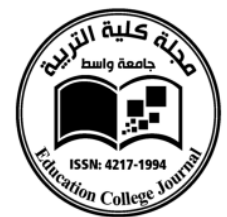

مجلــــة كليـــة التربيــة

ج) اللغة العبرية هي لغة آدم وحواء في الجنة وأن عمرها آلاف السنين.

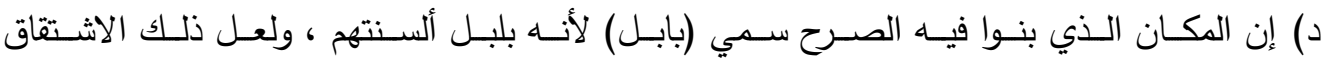

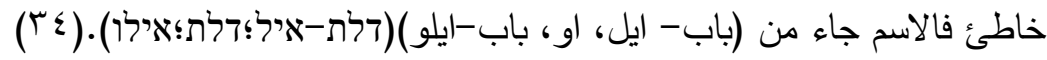

وبعد ذلك العرض لا نجد سبب لخوف يهوه من الإنسان الضعيف، فالبرج والصرح لا ليقف أمام عظمة وقدرة الخالق، كما أن الإنسان لم يتوقف عن صنع تلك الصروح والأبراج بعد هذه القصة.

وما تلك القصة إلا بداية لصنح نسب مشرف بانتمائهم إلى عابر الذي حافظ على لغة السماء.

المبحث الثالث : انفعال الغضب (The emotion angry)(הרגשישלהכעס)

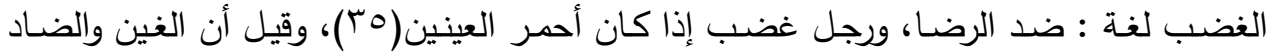

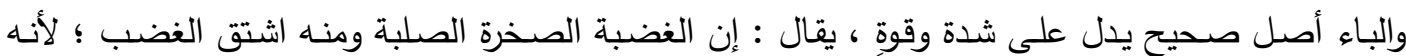

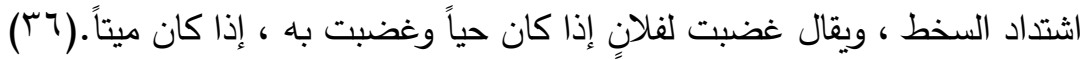

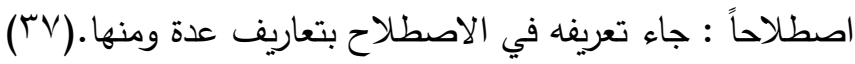

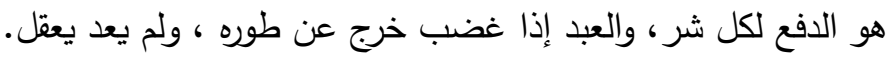

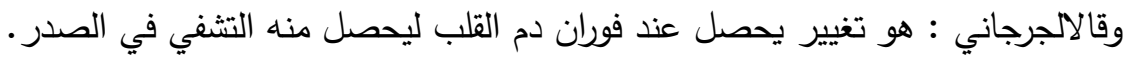
وقال الراغب : هو ثوران دم القلب إرادة ، أو بطلب الانتقام.

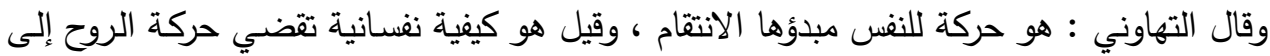

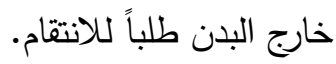

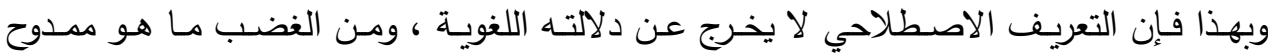

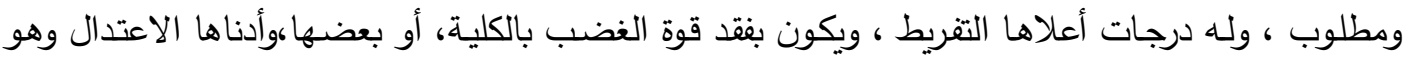

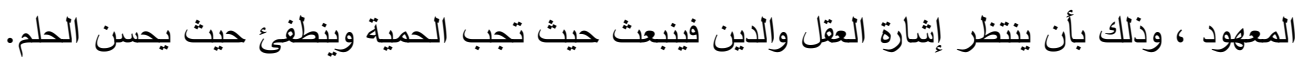

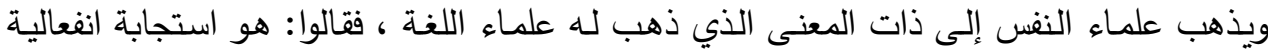

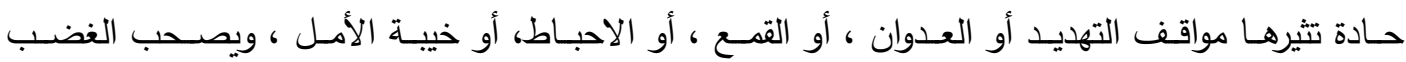

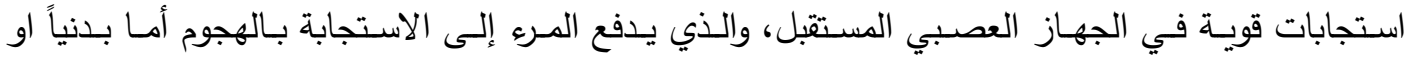
لفظياً.) (r^) وهذا يظهر كله على ملامح الغضبان كأحمرار الوجه والعينين ، وغليان دم القلب بطلب الانتقام ؛ وهذه الحالة قد تكون مؤقتة أو طويلة الأمد بحسب طبيعة الفطيان كادرار الثخص. 
ويقسم الغضب على قسمين ، الأول: الغضب صفة ثابتة لله تعالى على الوجه اللائق به، وهي من صفاته الفعلية (qج). والثاني غضـب الإنسـان ومنها يكونما هو إيجابي كغضبـه لدينه ومنه مـا هو سلبي كغضبه لشيء زائل.

إذاً فالغضء رائ من الصفات غير المحمودة أو المذمومة، وإنما يحدد ذلك بتحديد القصد والغاية.

مشهد غضب يهوه في التوراة: (Scene anger of Jehovah in the Bible) جاء في السفر مشهح لغضب يهوه على حواء وآدم، بعد أن نهاهم عن الأكل من أحد أثجار جنة عدن ، غير أن الحية أغوتهما فأكلا منها فقال يهوه لحواء : 》 لماذا فعلت هذا ، فأجابت المرأة : الحية أغوتني فأكلت « سفر التكوين: ץ: ץ ا. ؛ أما عند سؤاله لآدم: 》 هل أكلت من الشجرة التي أوصيتك أن لا تأكل منها ،

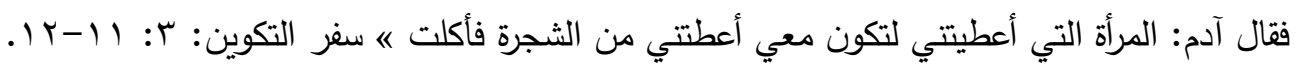
وكأنه أراد ان يهرب من المسؤولية ويلقي بحملها على المرأة ، فكان نتيجة فعلتهها تلك أن (يهوه) صب غضبه عليهما بأن أخرجهما من جنة عدن / فطرد آدم وأقام الكروبيم( • ع) شرقي جنة عدن ه سفر التكوين: r: ع r . وهنا تمزج التوراة بين غضب (يهوه) وخوفه من آدم وهذا ما نلمسهـ من قوله: اوالآن لعله

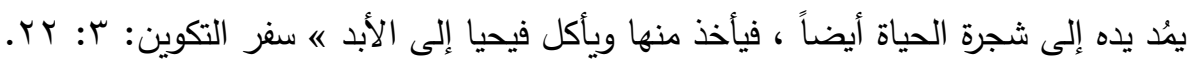
وما نلاحظه على تلك القصة، هي اصباغ صفة الجهل على (يهوه) فهو لم يحظر على الإنسان الأول أن يأكل من شجرة الحياة، وإنما اقتصر ذلك على شجرة معرفةالخير والشر، فلو أكل الإنسان أولاً من شجرة الحياة. كان لاكتسب صفة الخلود ، ولما بقى معنى لقول (يهوه) أنه سيُميت الإنسان ، فكيف لم ينتبه إلى ذلك.

كما كيف كان (ليهوه) أن يحاسب الإنسان لو أخطأ وهو لا يدرك أي معنى للخير والثر؟ ولعل مثل تلك الآيات هي من عزز أنه لا حساب بعد الموت(1). كما أننا نجد أن الإنسان أكل من الثجرة وهو لا يميز بين الخير والثر ، وأنه كان فريسة لحيوان وصف بالمكر وهي (الحية) فهل يُحاسب المخلوق غير المميز عن ما ارتكب من فعل؟ وبعد أن ميز وعقل

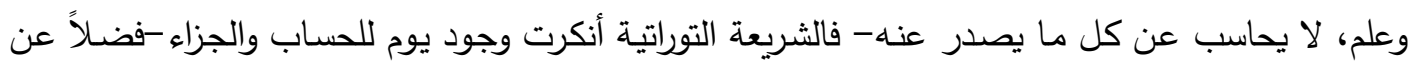
ذلك أن يهوه قال لآدم: 》 يوم تأكل منها موتاً تموت 《. غير أن آدم عاش بعد ذلك مئات السنين.

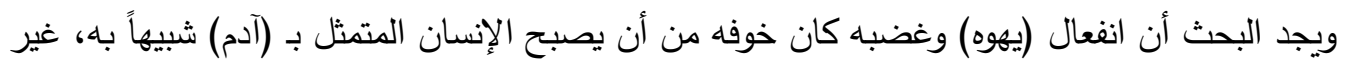
أننا نرى أن تلك الحبكة مبهمة، كيف تهب شجرة خاصية الحياة وأخرى معرفة الخير والثر ؛ ونحن نتسأل لماذا لم يأكل منهما معاً قبل أن يسأله أٔكلت من الثجرة ، وما هو أغرب منه؛ لماذا لم تأكل الحية من تلك الثمار 
المبحث الرابع : انفعال الندم (The Emotion Remorse)(הרגששלהכעס)

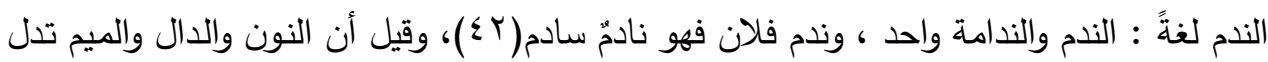

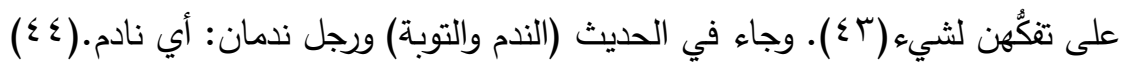

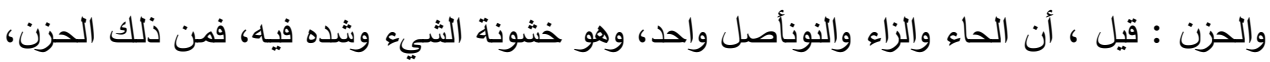

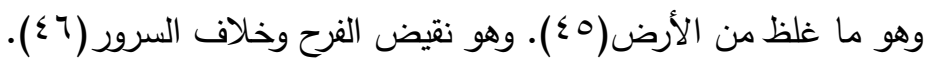

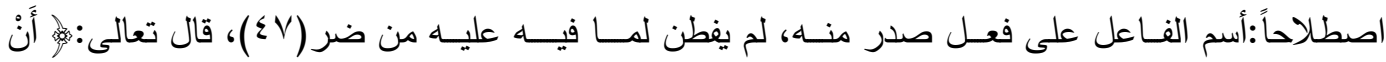

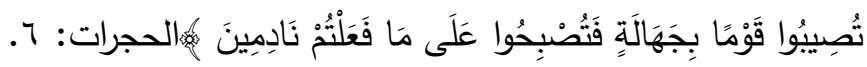

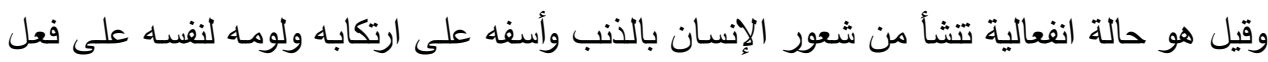

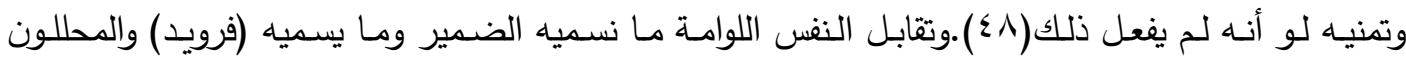

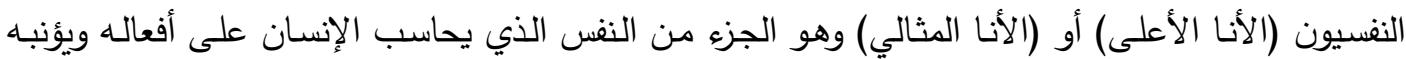

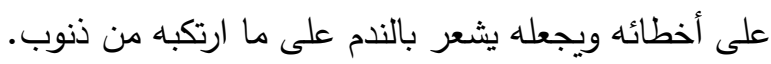

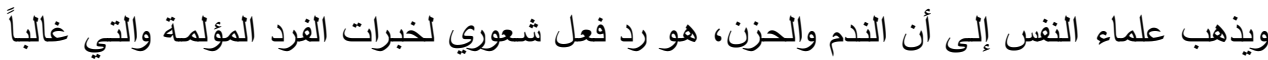

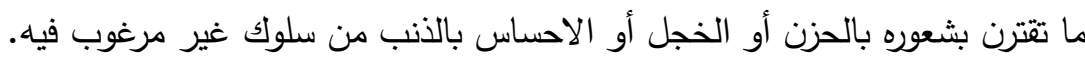

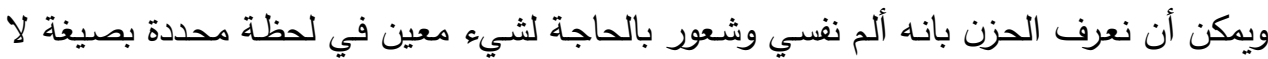
يستطيع الفرد تحملها نابعة من الافتقاد لثيء ما والرغبة الثديدة فيه.مشهد ندم وحزن يهوه في سفر التكوين.

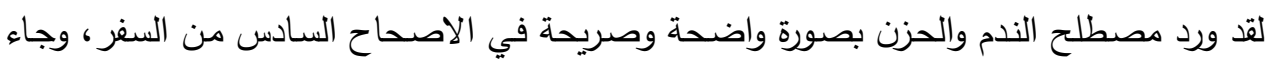

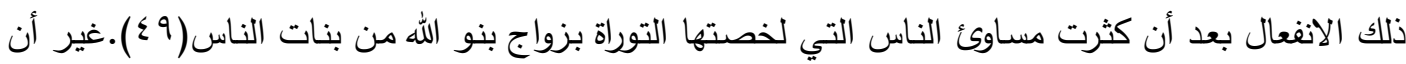

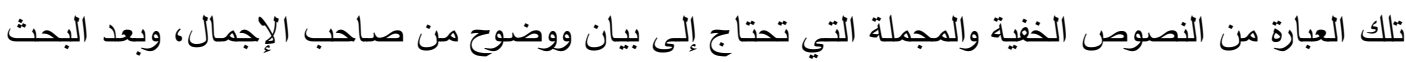

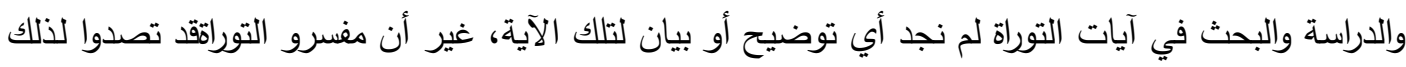

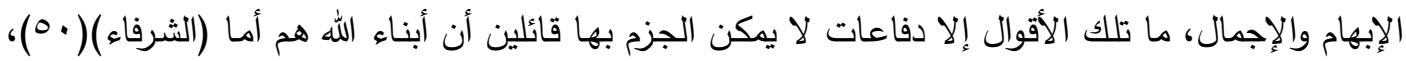

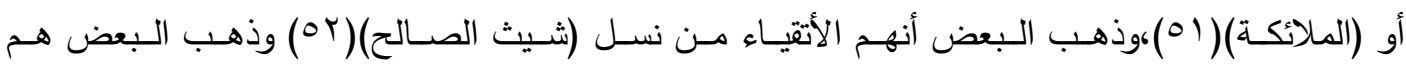

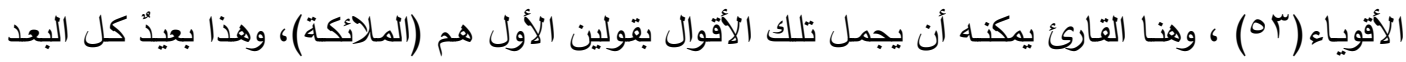

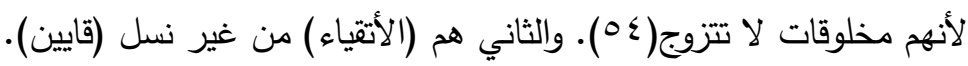

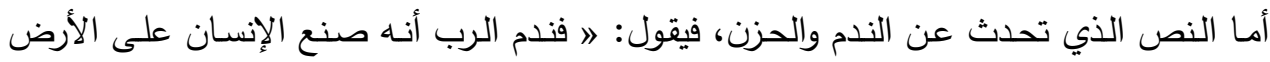

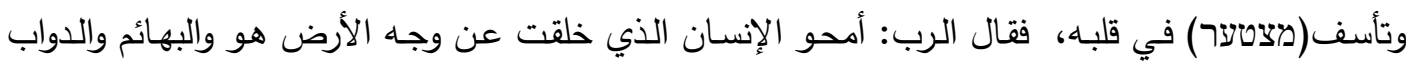

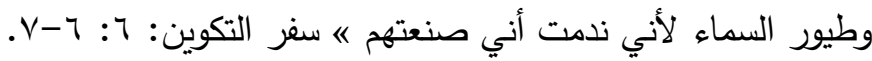


ولعل ذلك الندم هو من أقسام الندم السلبي، وكأن صاحبه يشعر بذنب غير معروفالمصدر أو مبهم ، وهذه المشاعر وهمية مشبعة بالمبالغة لا ترتبط بخطأ واضح وكأن الخطأ المرتكب لا يغتفر • لا سيما وأننا لا نعرف من هم أبناء الله.

وقد حاول بعض الشراح وتصدوا لمثل تلك الألفاظ ودافعوا مفسري تلك الألفاظ قائلين أن الندم يتتاقض مع صفات (يهوه) فهذا النص يناقض وما جاء في سفر العدد الاصحاح (rr) الآية (9 ( ) حيث جـاء :» ليس الله ابن انسـان ليندم «• ولا شك أنـه منزه.(00) وأن الندم معنـاه الثفقة والرقة والرحمـة، وأن استعمال مثل هذه الألفاظ البشرية في جانب الله جائز؛ ليقرب إلى عقولنا الأمور المعنويـة فهو يخاطبنا بلغتتا لا لغة المالأكة.

ويجد البحث ما تلك الألفاظ إلا ألفاظ دخيلة على التوراة العبريسة مستوحاة من نصوص توراة بلاد الرافدين التي جاء فيها : " وحزن الإله من ضجيجهم ، سمع انليل ضجيجهم ، وقال للآلهة العظام، لقد صار ضجيج البشر ثقيل الوطأة لقد منعوا بصخبهم النوم «.(ب (0) فبعد ضياع التوراة وإعادة كتابتها لعلهم تأثروا بمثل تلك النصوص. وما نستتتجه بعد قراءتتا للآيات السابقة نجد. بون. ا- إن عقاب يهوه لقوم نوح كان رد فعل على شيء مبهم ، وأن العقاب لا ينسجم مـع الذنب، وقد حس (يهوه) بذلك لذا نجده يوعد (نوح) بأنه لم يعد يهلك العالم بطوفان آخر . r- - إن (يهوه) لا يعلم بما سيكون في المستقبل ؛ لأنه حين خلق الإنسان قال عنه في الاصحاح الأول أنه (حسن) وعن كل المخلوقات، فكيف يندم عن وصفه بتلك الأوصاف. 
النسيان لغة : قيل أن النون والسين والياء أصلان صحيحان، يدل أحدهما على إغفال الثيء ، والثران ، الثاني

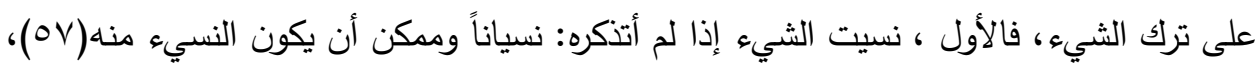
والنسيان خلاف الذكر .

وفيالاصطلاح : ترك شيء من غير علم، ولا ينتبه له بأدنى تتبيه، كما عرف بأنه ترك ما استودع أما

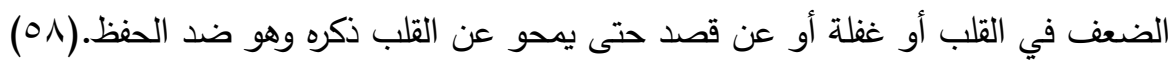
ويذهب علماء النفس إلى تعريفه : بأنه فقدان طبيعي، جزئي أو كلي، مؤقت أو دائمي، لما اكتسبناه من

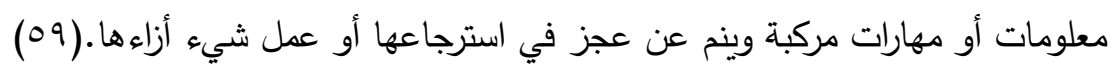
وبهذا نجد أن التعريف السابقة اللغوية والاصطلاحية والنفسية، تكاد تتشابه في دلالتها على المعنى ذاته.

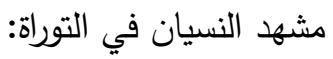
بعد أن أغرق (يهوه) الأرض بالطوفان، فأهلك كل حي على وجه الأرض من الناس والحيوانات باستثناء

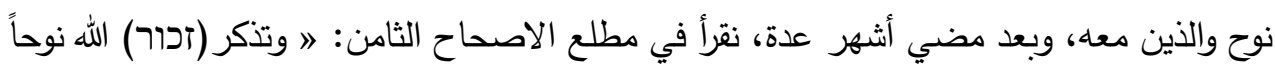

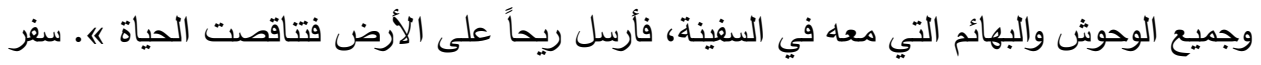
التكوين: ^: 1-r.

وهنا نسأل هل نسى (يهوه) نوح ومن معه وكان عليه أن يستعيد ذاكرته، ليتذكر من أقام معه أهـاء

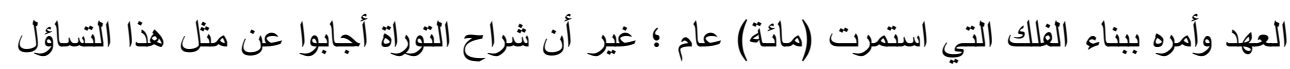

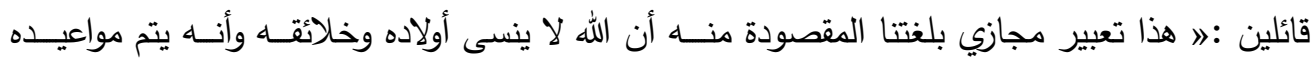

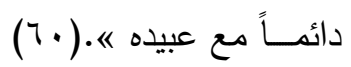

وهذا يعني أن الله فاض بمراحمه على نوح.( (7) وعلى ذلك يعلق افرام السرياني قائلاً : » فلما بلغ لنوح

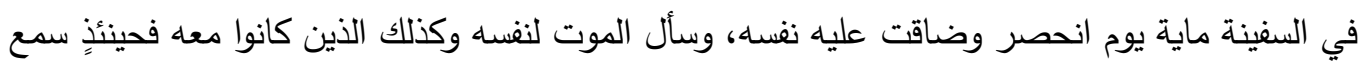

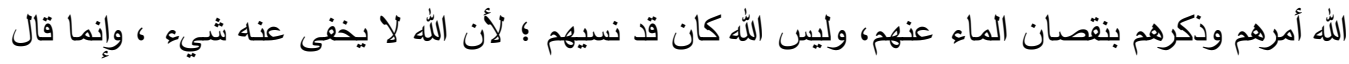

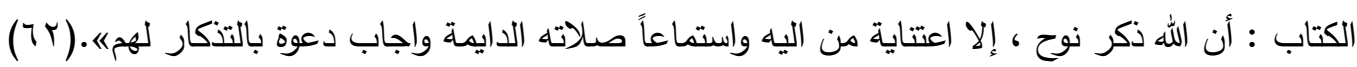


وبعد أن أجهد مفسرو الكتاب المقدس أنفسه في بيان معنى النسيان حتى أنهم ظنوا قد أقنعوا القارئ،

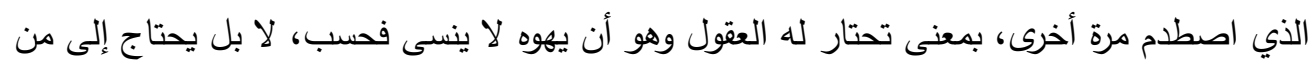

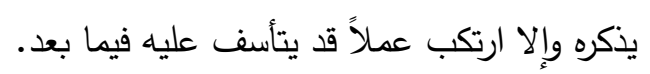

فيقول يهوه لنوح ومن معه بعد أن خرجوا من السفينة : " هذه علامة العهد الذي أقيمه بيني وبينكم وبين

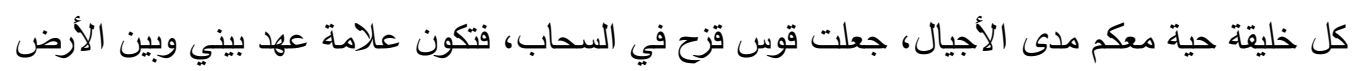

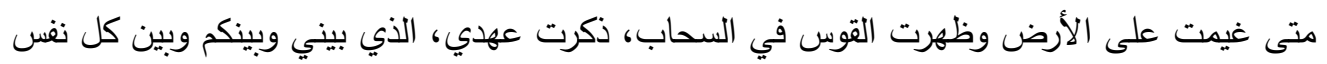

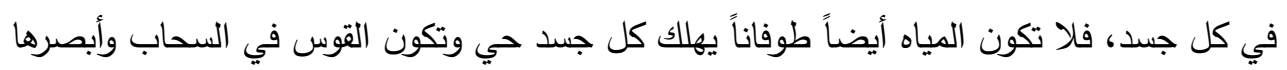

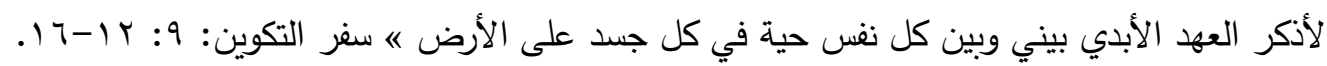
غير أن الشراح أولوا هذا المعنى قائلين : ما القوس في السماء إلا تذكرة لنا، أي أن الله يذكرنا بأمانته

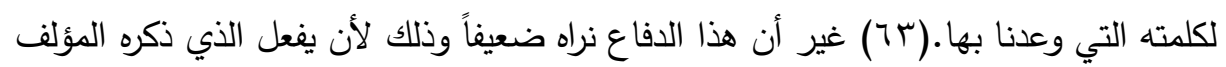

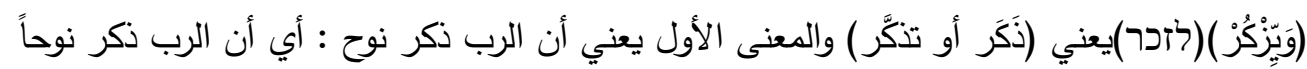

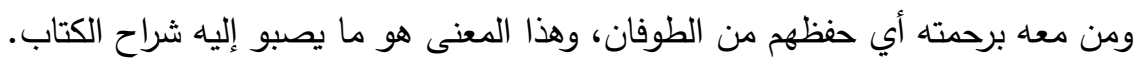

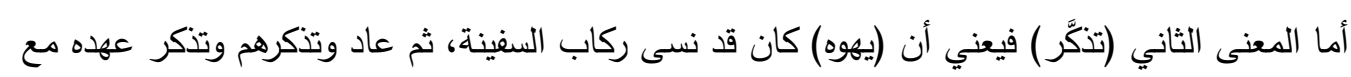

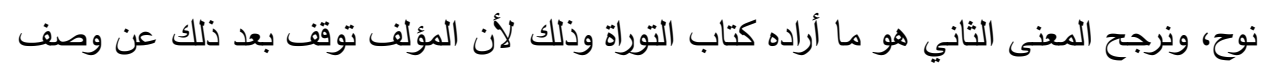

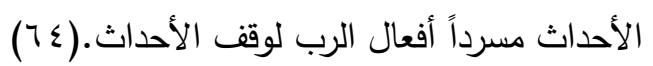

وما يعزز ما ذهبنا إلى ترجيحه صناعة (يهوه) للقوس، والسؤال هنا، من يصنع هذه الظاهرة ! أ تحدث

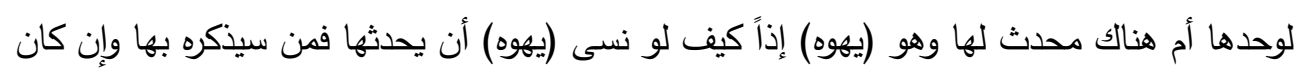
(يهوه) نسى فما فائدة تلك العلامة وإن ظهرت فربما سينسى سبب دلالتها - حاشا لله وترى هدف القصة ، هو نفي قدرة الرب الكلية ويجعله كالإنسان ينسى ويتذكر . نقول : ما تلك إلا ظاهرة طبيعية تحدث من انكسار أشعة الشمس على قطرات المطر. 
- - صورت التوراة يهوه بصورة انسان بتملكه تلك الصفات مثل الخوف، الحزن، الندم، النسيان الناتجة عن الانفعال؛ وبما ان الانفعال حالة خارجية تؤثر في المنفعل بفعل اقوى منه تدفعه للأقدام على سلوك غير مدروس وهذا لا يصدر عن حكيم.

- - صورت التوراة يهوه يمر بمشاهد الخوف، وهو انفعال ينشأ عند تعرض الفرد لمؤثرات مصحوبة بمخاطر ولا يجوز هذا الانفعال للرب كونه اعظم من البشر فكيف يخاف من الانسان الضعيف.

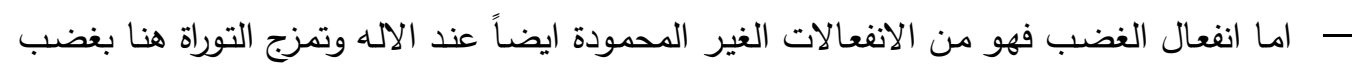
يهوه وخوفه من ادم اي خوفه من ان يصبح متشبهاً به بعد اكله من شجرة معرفة الخير والثر ولا داعي لذلك الخوف من انسان خلقه بيده. - - ماما عن انفعال الندم فتدخل التوراة في تتاقض عندما تقول ان الرب ندم على خلق البشر وبين ما تقرأ من شروح أخرى تنفي ذلك (ليس الله ابن انسان فيندم) وان الندم هنا معناه الثفقة، والرقة، والرحمة. وان يهوه قد ندم ايضاً بعد الطوفان، فوعد نوح بأنه لم يهلك العالم بطوفان اخر . - مفي مشهد النسيان صورت التوراة يهو بمشاهد يتعرض بها للنسيان، لا بل يحتاج الى من يذكره والا ارتكب عملاً قد يتأسف عليه فيما بعد، جسد ذلك قصة علامة القوس الانفة الذكر. 


\section{المادر والمراجع}

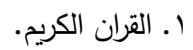

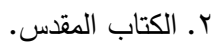

r. أساطير التوراة الكبرى، د. كارم محمود عزيز ، طا ، ج . . ب ، مكتبة النافذة.

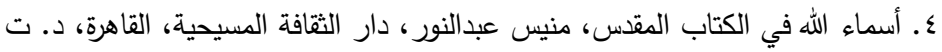

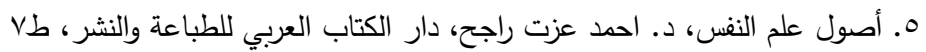

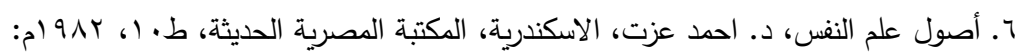

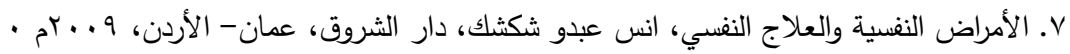

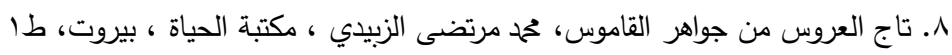
9 9. تاريخ وعقيدة اليهود، د. كامل سعفان، دار الاعتصام : 17 V.

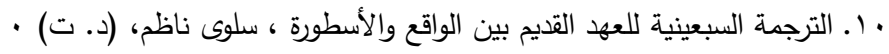
11 إ. تنسير سفر التكوين، افرام السرياني .

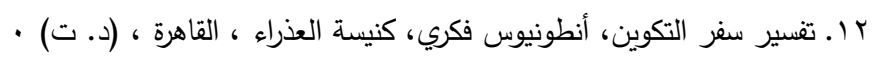

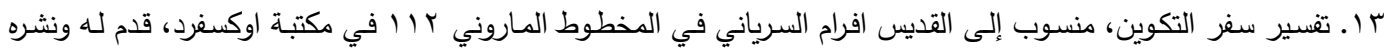
الأب يوحنا ثابت رئيس جامعة الروح القس - الكسليك

ـ ا ـ التلمود كتاب اليهود المقدس، أحمد ابيش قدمه : د. سهيل زكار ، دار قتيبة الكابل

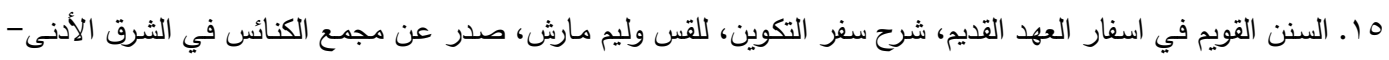

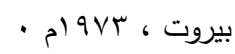

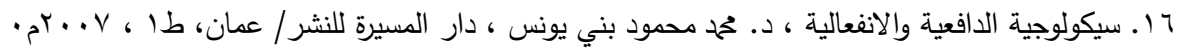

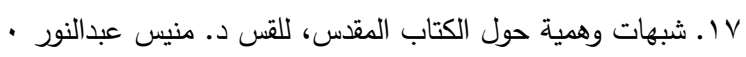
1/ اـ شرح العقيدة الواسطية، لابن تيمية المؤلف محم بن صالح العثمين(سخة منقحة) سعد بن فواز الصميل .دار ابن الجوزي . $ه \leqslant$ ا

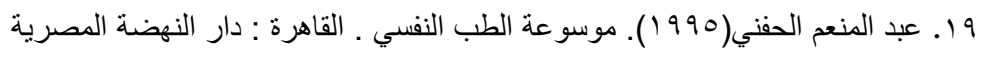

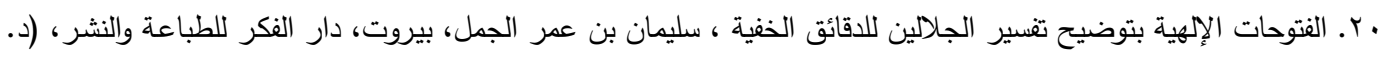

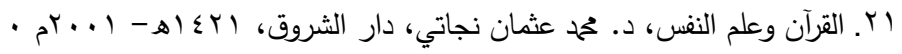

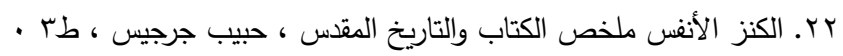

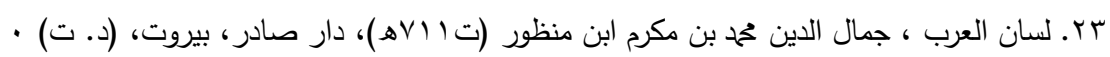

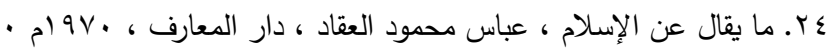




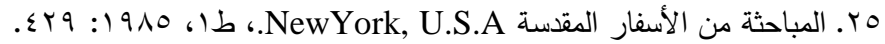
דr. المدخل إلى الكتاب المقدس ومقدمة أسفار العهد القديم، كوركيس متى، (د. ت).

V V. مدخل علم النفس، الندال دافيدوق ، ترجمة الدكتور سيد الطواب وآخرون، منشورات مكتبة التحرير، طب •

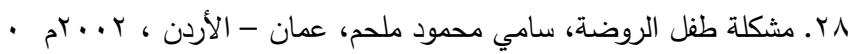
9r. معالم سيكولوجية الطفولة، ابراهيم كاظم العطماوي، وزارة الثقافة والإعلام، بغداد- العراق، 911 ام • . • r. المعجم الوسيط، مجمع اللغة العربية بالقاهرة، ابراهيم مصطفى، أحمد الزيات دار الدعوة:

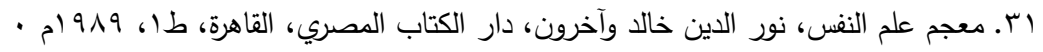
rr. المفردات في غريب القرآن، أبو القاسم الحسين بن محم الراغب الأصفهاني، راجعه وائل أحمد عبدالرحمن، القاهرة، المكتبة

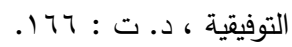

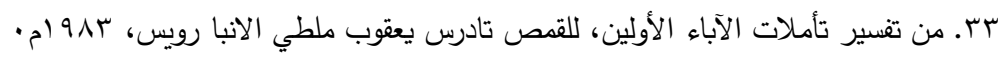

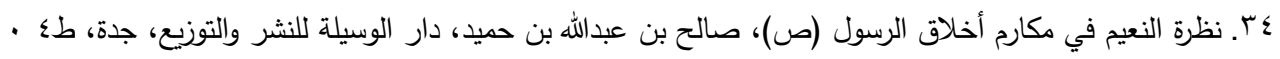




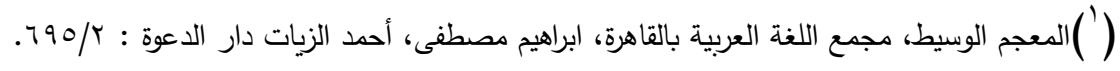

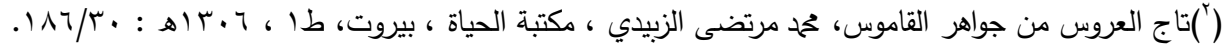

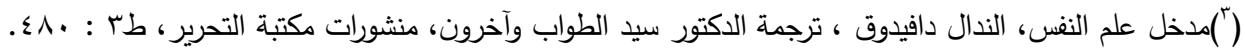

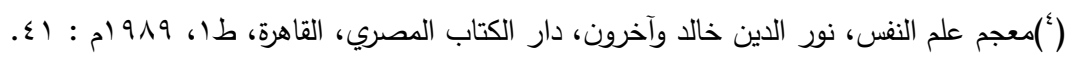

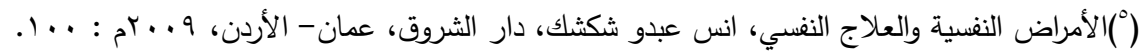

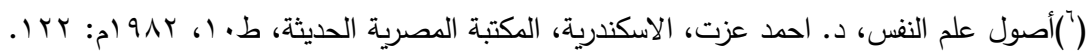

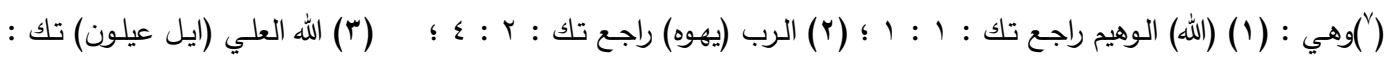

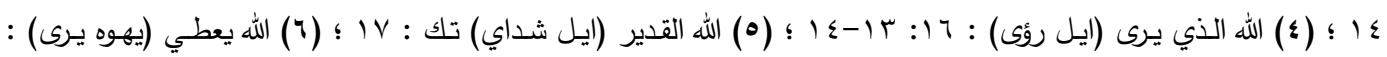

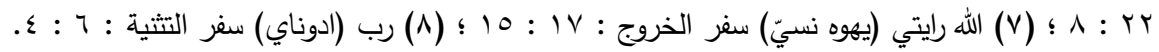

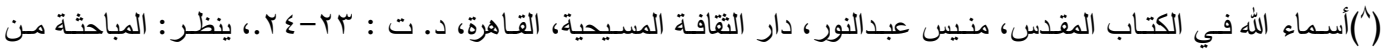

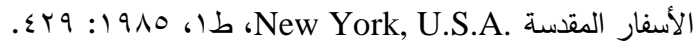

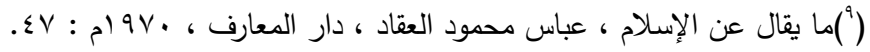

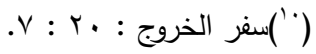

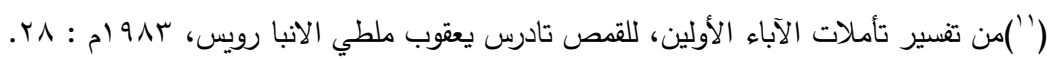

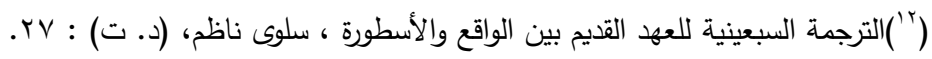

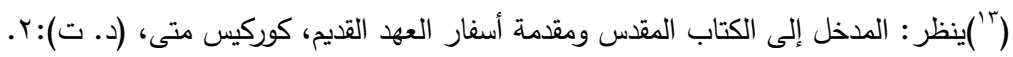

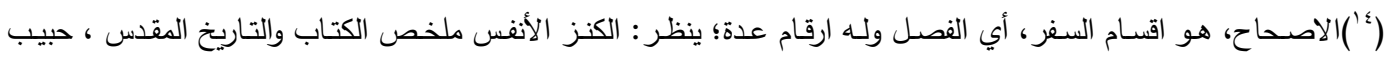

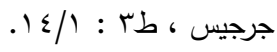
T)

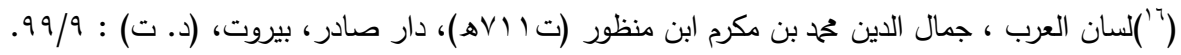

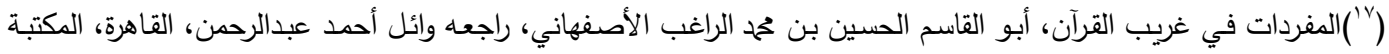

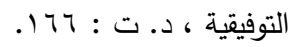

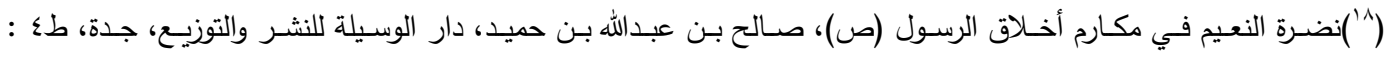
$.19 \ldots 10$

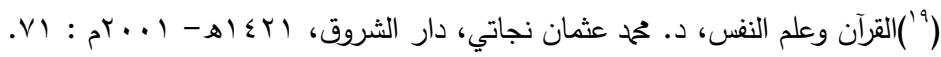

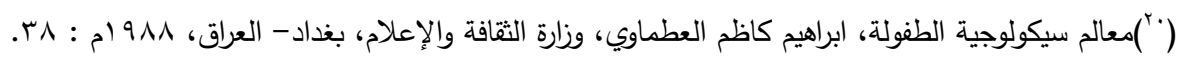

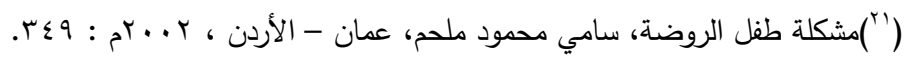

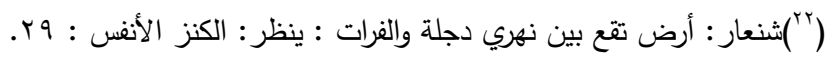
(r)

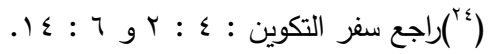




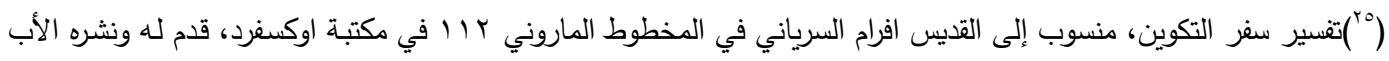
يوحنا ثابت رئيس جامعة الروح القدس - الكسليك : (")

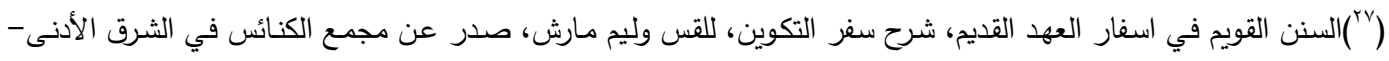

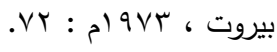

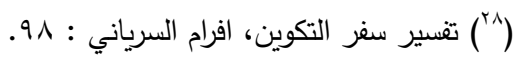

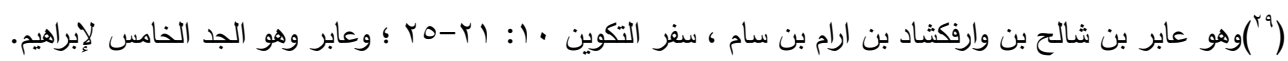

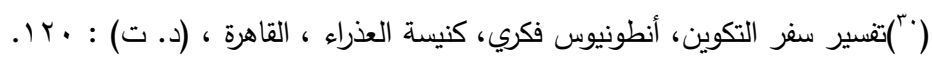
(1)

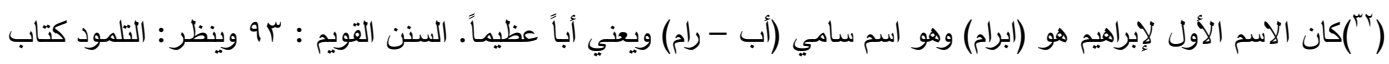

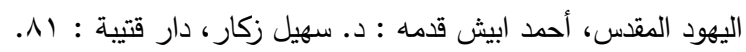

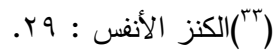

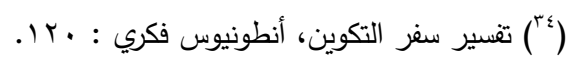

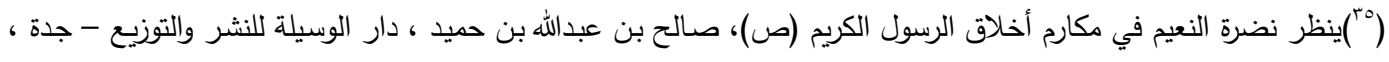
19.10: ط

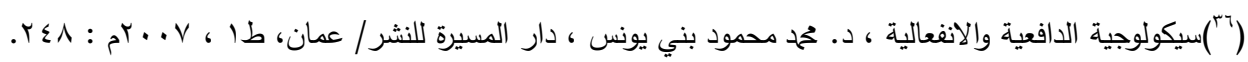

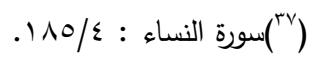

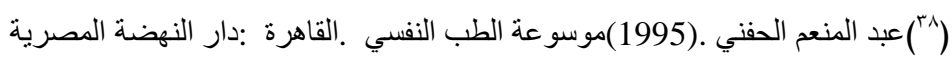

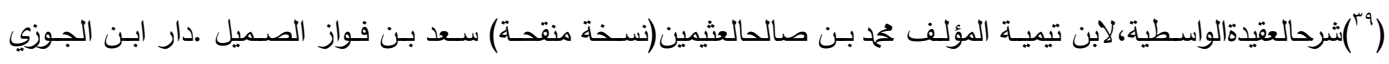

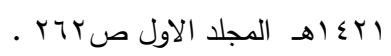

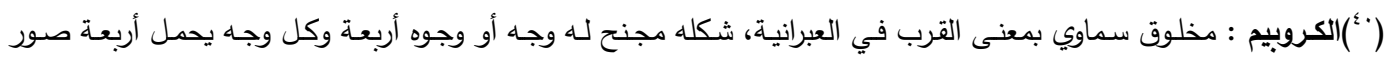

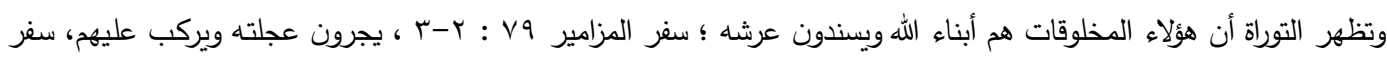

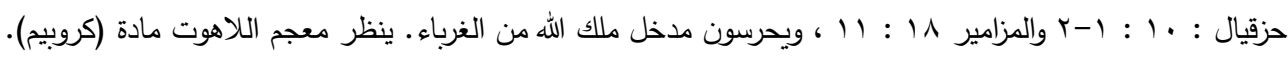

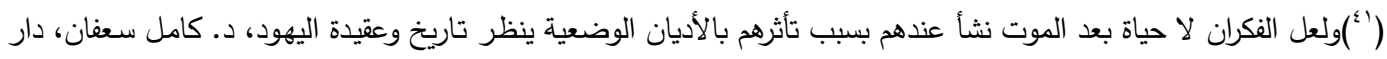

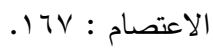

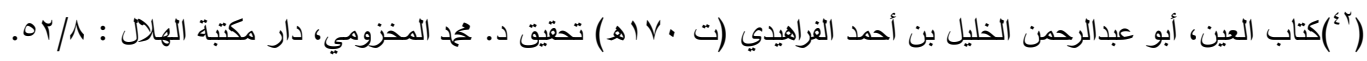

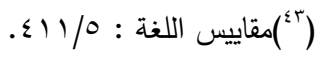

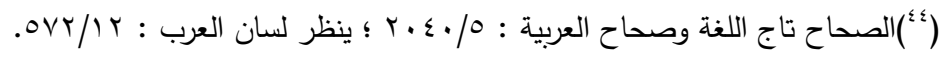

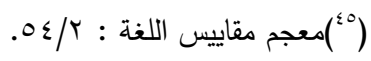

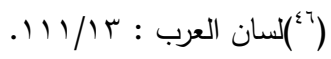

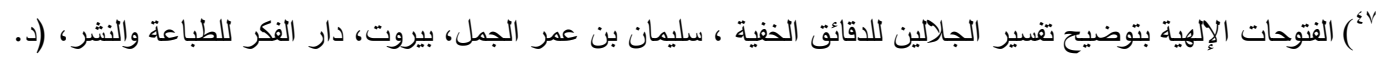
$.1 \vee \wedge / \varepsilon$ : (ت 


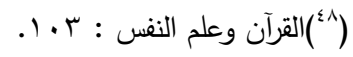

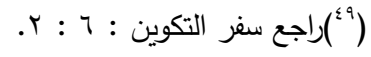

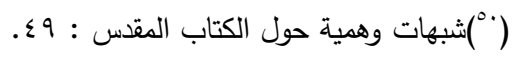

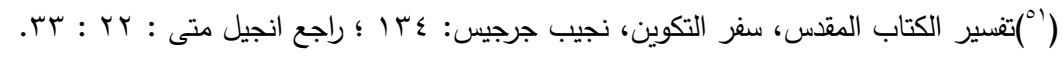

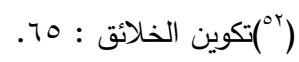

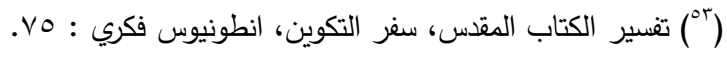
( )

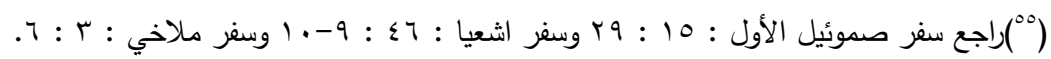

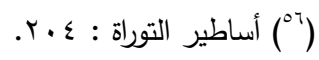

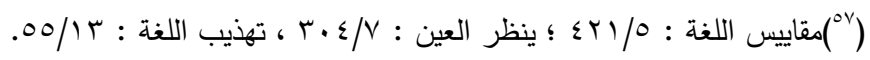

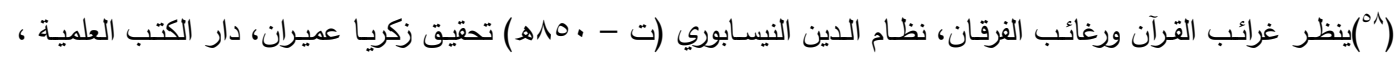

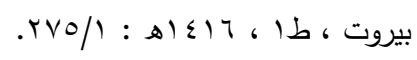

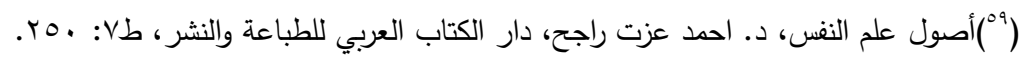

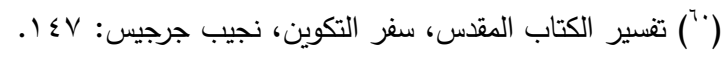

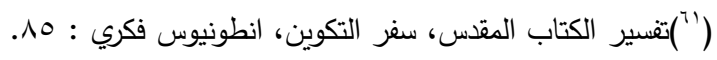
. VV : (T)

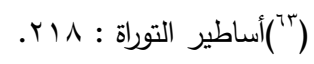

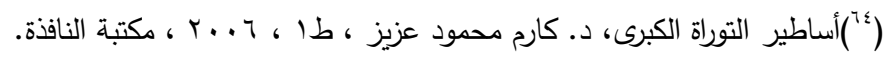

